\title{
GENETIC AND ENVIRONMENTAL DISPERSION PARAMETER ESTIMATION BY TEST INTERVAL METHOD IN DAIRY SHEEP ${ }^{1}$
}

\author{
Andreja KOMPREJ ${ }^{2}$, Dragomir KOMPAN ${ }^{3}$, Milena KOVAČ ${ }^{3}$
}

Received November 12, 2010; accepted April 15, 2011. Delo je prispelo 12. novembra 2010, sprejeto 15. aprila 2011.

\section{Genetic and environmental dispersion parameter estimation by test interval method in dairy sheep}

Genetic and environmental parameters for 38983 test-day records of daily milk yield (DMY), fat (FC) and protein (PC) content, collected between 1994 and 2002, were estimated on 3,068 dairy ewes of the three Slovenian breeds. A multivariate restricted maximum likelihood method was used for estimation, where every test-day record was treated as a different trait. Fixed part of the multitrait animal model for DMY, FC, and PC included breed and lambing season as classes, while stage of lactation, parity, and litter size were covariates. Random part of the model contained additive genetic effect and the effects of flock test month and permanent environment over lactations. Heritability estimates for individual test-days were between 0.10 and 0.23 for DMY, 0.09 and 0.18 for FC, and 0.19 and 0.28 for PC. The flock test month effect explained most of the phenotypic variance: 0.18 to 0.41 for DMY, 0.26 to 0.45 for FC, and 0.24 to 0.44 for PC. A lower variance ratio was explained by the permanent environment effect over lactations: 0.09 to 0.15 for DMY, 0.02 to 0.11 for FC, and 0.02 to 0.09 for PC. Additive genetic correlations between individual test-days were high in all three milk traits for adjacent months of lactation. They decreased when the interval between months of lactation increased. The structure of additive genetic correlations showed that the observed milk traits in the different stages of lactation were genetically not the same trait, since the correlations between distant months of lactation were lower than one.

Key words: dairy sheep / milk yield / milk composition / genetic parameters / environmental parameters / test-day records / test interval method / variance-covariance components

\section{Ocena genetskih in okoljskih parametrov disperzije z večlastno- stnim modelom $z$ intervali pri mlečnih ovcah}

Ocenjevali smo genetske in okoljske parametre za 38983 meritev na kontrolni dan za količino mleka (DKM) ter vsebnost maščobe (VM) in beljakovin (VB) v mleku pri 3068 mlečnih ovcah treh slovenskih pasem. Meritve so bile zbrane med leti 1994 in 2002. Za oceno parametrov smo uporabili večlastnostno metodo omejenega največjega verjetja, kjer je vsaka meritev na kontrolni dan obravnavana kot druga lastnost. Sistematski del večlastnostnega modela živali za DKM, VM in VB je vključeval pasmo in sezono jagnjitve kot razrede, stadij laktacije, zaporedna jagnjitev in velikost gnezda pa so bili vključeni kot kovariable. Naključni del modela je vseboval aditivni genetski vpliv živali, vpliv skupnega okolja v tropu in vpliv permanentnega okolja živali. Heritabilitete za posamezne mesece laktacije so bile med 0,10 in 0,23 za DKM, med 0,09 in 0,18 za VM in med 0,19 in $0,28 \mathrm{za}$ VB. Skupno okolje $\mathrm{v}$ tropu je pojasnilo največji del fenotipske variance: 0,18 do 0,41 za DKM, 0,26 do 0,45 za VB in 0,24 do 0,44 za VB. Vpliv permanentnega okolja živali je pojasnil manjši delež variance: 0,09 do 0,15 za DKM, 0,02 do $0,11 \mathrm{za} \mathrm{VM}$ in 0,02 do $0,09 \mathrm{za} \mathrm{VB}$. Aditivne genetske korelacije med posameznimi lastnostmi mlečnosti sosednjih mesecev laktacije so bile močne in so se $\mathrm{z}$ oddaljevanjem mesecev laktacije zmanjševale. Struktura aditivnih genetskih korelacij kaže, da lastnosti mlečnosti v različnih stadijih laktacije genetsko niso ista lastnost, saj so korelacije med oddaljenimi zapisi manjše od ena.

Ključne besede: mlečne ovce / mlečnost/mleko / sestava / genetski parametri / okoljski parametri / zapisi na dan meritve / metoda $\mathrm{z}$ intervali / komponente varianc in kovarianc

1 The article is part of the doctoral dissertation »Prediction of breeding values with random regression models for longitudinal milk records in sheep «, issued by Andreja Komprej, Ph.D., supervisor Assoc. Prof. Milena Kovač, Ph.D. / Prispevek je del doktorske disertacije »Napovedovanje plemenskih vrednosti s pomočjo modelov z naključno regresijo za zaporedne meritve mlečnosti pri ovcah«, mentorica izr. prof. dr. Milena Kovač

2 Univ. of Ljubljana, Biotechnical Fac., Dept. of Animal Science, Groblje 3, SI-1230 Domžale, Slovenia, Ph.D., andreja.komprej@bf.uni-lj.si

3 Same address, Assoc. Prof., Ph.D. 


\section{INTRODUCTION}

In Slovenia, three dairy sheep breeds are mostly reared: Bovec breed, Improved Bovec breed (with EastFriesian), and Istrian Pramenka. Milk is processed into cheese and curd that are sold at home or in market halls. Sheep milk production in our climate is explicitly seasonal and coincides with vegetation. Lambings occur between February and April. Test-day records, collected according to ICAR regulations (ICAR, 2009) at monthly intervals are usually missing at the beginning of lactation due to relatively long suckling period (six to seven weeks on average). Considering short lactations in dairy sheep, ewes have on average only three to four test-day records per lactation. Milking period usually starts after the peak of lactation curve has been already reached and when daily milk yield is starting to decrease. Mating season starts in early autumn before lactation is completed, so breeding values should be available before mating season starts.

Genetic evaluations of milk traits in dairy sheep are nowadays mainly performed by application of testday records (El-Saied et al., 1998a, Serrano et al., 2001, Oravcova et al., 2005, Komprej et al., 2009). Some advantages were found in such modelling of records (Ptak and Schaeffer, 1993, Serrano et al., 2001) in comparison to lactation yields (El-Saied et al., 1998a, El-Saied et al., 1998b, Portolano et al., 2001). The accuracy of genetic evaluations by this approach is higher due to a larger number of records per animal and better modelling of environmental effects on test-day. There is no need to wait until the end of lactation, what enables the selection of animals before new breeding season on records from current lactation. The method thus shortens generation interval (Brežnik, 1999) and increases genetic progress at the same intensity of selection (Swalve, 2000). The genetic analysis could be performed more frequently by this approach, what is important in dairy sheep, where the best animals are selected before the lactation is completed (Brežnik, 1999, Andonov, 1994). Modelling test-day records by the repeatability animal model assumes the common shape of the lactation curve for contemporary group of animals (Ptak and Schaeffer, 1993) and the constant variance along the lactation trajectory. Milk traits are considered to be genetically the same traits during lactation.

The second way of using test-day records directly is multi-trait modelling where lactation is partitioned into intervals containing at most one record per animal. Testday records in different intervals are treated as different traits (Meyer et al., 1989, Pander et al., 1992, Pander et al., 1993, Swalve, 1995). The method is known as test interval method (TIM) and was described 40 years ago by Everett and Carter (1968) and Sargent et al. (1968). This kind of modelling is frequently used in dairy cows (Meyer et al., 1989, Pander et al., 1992, 1993, Swalve, 1995, Schaeffer and Jamrozik, 1996, Schaeffer, 1998) and seldom in dairy sheep (Baro et al., 1994, Serrano et al., 2001). Recently, the test-interval method was used for dairy buffaloes (Tonhati et al., 2008).

The test interval method also enables estimation of (co)variances between individual test-day records within lactation. Correlations among milk traits, especially yields of milk, fat, and protein, on consecutive test-days are generally high, depending on the length of interval between tests (Ali and Schaeffer, 1987). As mentioned by Vargas et al. (1998), the heterogeneity of variances during lactation and the patterns in genetic and phenotypic correlations suggest that a multiple trait approach is more accurate than the repeatability model.

In the present paper, genetic and environmental dispersion parameters for daily milk yield and milk components in Slovenian dairy sheep were determined by the test interval method using test-day records.

\section{MATERIAL AND METHODS}

\subsection{DATA}

Data from 3,068 ewes were collected between 1994 and 2002 in 36 flocks according to ICAR regulations by the A4 method (ICAR, 2009). Test-day records for daily milk yield (DMY), fat (FC) and protein (PC) content of Bovec (B), Improved Bovec (IB) and Istrian Pramenka (IP) dairy breeds were obtained from the database of Slovenian breeding programme for small ruminants. The initial set of data contained 41,794 records. Only records without missing values for DMY, FC, and PC, which were collected between the $5^{\text {th }}$ and the $244^{\text {th }}$ day of lactation, were used in the analysis. Furthermore, at least three test-day records were required within lactation. DMY was limited to at least $50 \mathrm{~g}$. FC ranged from $1.5 \%$ to $18 \%$ and PC between $2.0 \%$ and $13 \%$. Records with parity 11 or more were rare and thus discarded. After this editing, $7 \%$ of the data were discarded. Thus, the final data set resulted in 38,983 test-day records for all three breeds together (Table 1).

The largest amount of test-day records was collected during the second and the sixth month of lactation (Table 1). The average DMY of all three breeds together was $1022 \mathrm{~g}$ with $6.62 \% \mathrm{FC}$ and $5.51 \%$ PC. According to the stage of lactation, the average DMY was decreasing from the first $(2,073 \mathrm{~g})$ to the eighth $(492 \mathrm{~g})$ month of lactation. Due to negative correlation between DMY and milk components, FC increased from $4.53 \%$ to $7.95 \%$ 
Table 1: Descriptive statistics according to the month of lactation for breeds together Preglednica 1: Opisna statistika glede na mesec laktacije za vse pasme skupaj

\begin{tabular}{|c|c|c|c|c|c|c|c|}
\hline \multirow{2}{*}{$\begin{array}{l}\text { Month of } \\
\text { lactation }\end{array}$} & \multirow{2}{*}{$\begin{array}{l}\text { Number of } \\
\text { records }\end{array}$} & \multicolumn{2}{|c|}{ Daily milk yield (g) } & \multicolumn{2}{|c|}{ Fat content $(\%)$} & \multicolumn{2}{|c|}{ Protein content, $\%$} \\
\hline & & Mean & $\mathrm{SD}$ & Mean & $\mathrm{SD}$ & Mean & SD \\
\hline 1 & 1465 & 2073 & 1017 & 4.53 & 1.35 & 4.71 & 0.49 \\
\hline 2 & 5632 & 1755 & 756 & 5.37 & 1.03 & 4.69 & 0.51 \\
\hline 3 & 7248 & 1290 & 581 & 5.99 & 1.06 & 4.90 & 0.54 \\
\hline 4 & 7619 & 941 & 443 & 6.57 & 1.18 & 5.28 & 0.65 \\
\hline 5 & 7226 & 714 & 356 & 7.15 & 1.35 & 5.84 & 0.90 \\
\hline 6 & 5660 & 564 & 304 & 7.69 & 1.54 & 6.40 & 1.18 \\
\hline 7 & 2855 & 497 & 288 & 7.86 & 1.60 & 6.57 & 1.19 \\
\hline 8 & 1278 & 492 & 273 & 7.95 & 1.70 & 6.64 & 1.10 \\
\hline Together & 38983 & 1022 & 692 & 6.62 & 1.59 & 5.51 & 1.07 \\
\hline
\end{tabular}

and PC increased from $4.71 \%$ to $6.64 \%$ during lactation. The standard deviation (Table 1) decreased from $1017 \mathrm{~g}$ to $273 \mathrm{~g}$ for DMY and increased from $1.35 \%$ to $1.70 \%$ for FC and from $0.49 \%$ to $1.10 \%$ for PC. The variation of DMY thus declined during lactation, while the variation of FC and PC increased at the same time.

The pedigree file contained 3534 animals of both sexes (Table 2), where 2244 animals were from breed B, 677 from breed IB and 720 from breed IP. Considering the fact that some ancestors from breeds B and IB are common, the sum of animals across breeds is not equal to 3534 . There were $2346(66.38 \%)$ animals of all breeds with at least one ancestor known, where the majority of data presented breed B. The number of base animals with both ancestors unknown in all three breeds was 1188 .

\subsection{METHODS}

By the test interval method, every test-day record (DMY, FC and PC) is treated as a different trait. Lactation was thus divided into eight intervals (months), where

Table 2: Number of animals with records and number of animals in pedigree file by breeds

Preglednica 2: Število živali z zapisi in število živali $v$ datoteki porekla po pasmah

\begin{tabular}{|c|c|c|c|c|}
\hline & \multicolumn{4}{|l|}{ Breed } \\
\hline & $\begin{array}{l}\text { Breeds } \\
\text { together }\end{array}$ & Bovec & $\begin{array}{l}\text { Improved } \\
\text { Bovec }\end{array}$ & $\begin{array}{l}\text { Istrian } \\
\text { Pramenka }\end{array}$ \\
\hline Ewes & 3068 & 1957 & 486 & 625 \\
\hline Pedigree & 3534 & 2244 & 677 & 720 \\
\hline Non-base & 2346 & 1458 & 500 & 440 \\
\hline Base & 1188 & 786 & 177 & 280 \\
\hline
\end{tabular}

each of them presented 30 days of lactation. The first month of lactation presented records measured between the fifth and $34^{\text {th }}$ day of lactation, and the eighth month presented records measured between the $215^{\text {th }}$ and $244^{\text {th }}$ day of lactation. Each animal had at most one record of DMY, FC, and PC on such interval. If a ewe had more than one record in one month, the closest one to the average day of lactation within the month was kept and the other was arranged into other intervals. After arranging the records, an eight trait model was used for DMY, FC, and PC.

Fixed part of the model (Equation 1 for the $1^{\text {st }}$ inter$\operatorname{val}\left(\mathrm{y}_{1 \mathrm{ijklm}}\right)$ and Equation 2 for intervals $\left.2-8\left(\mathrm{y}_{\mathrm{tijklm}}\right)\right)$ contained breed $\left(\mathrm{B}_{1 \mathrm{i}}, \mathrm{B}_{\mathrm{ti}}\right)$, lambing season $\left(\mathrm{LS}_{1 \mathrm{ij}}, \mathrm{LS}_{\mathrm{ti}}\right)$, stage of lactation $\left(\mathrm{x}_{1 \mathrm{ijkl \textrm {k }}}, \mathrm{x}_{\mathrm{tijk} / \mathrm{m}}\right)$, parity $\left(\mathrm{z}_{1 \mathrm{ijklm}}, \mathrm{z}_{\mathrm{tijklm}}\right)$, and litter size $\left(\mathrm{w}_{1 \mathrm{ijk} k \mathrm{~lm}}, \mathrm{w}_{\mathrm{tijk}}\right)$. In the $1^{\text {st }}$ interval, where the peak of lactation curve is found, the stage of lactation was modelled with quadratic regression, while linear regression was sufficient for intervals from the $2^{\text {nd }}$ to the $8^{\text {th }}$. Furthermore, parity was modelled with quadratic and litter size with linear regression. Random part of the model included flock-test-month effect as flock-year-month of test-day interaction $\left(\mathrm{fym}_{\mathrm{lk}}, \mathrm{fym}_{\mathrm{tk}}\right)$, permanent environmental effect over lactations $\left(\mathrm{p}_{1 \mathrm{ij}} \mathrm{p}_{\mathrm{til}}\right)$, additive genetic effect $\left(\mathrm{a}_{1 \mathrm{il}}, \mathrm{a}_{\mathrm{til}}\right)$, and residual $\left(\mathrm{e}_{1 \mathrm{ijklm}}, \mathrm{e}_{\mathrm{tijk} k \mathrm{~m}}\right)$.

$$
\begin{aligned}
& \mathrm{y}_{1 \mathrm{ijk} / \mathrm{m}}=\mathrm{B}_{11}+\mathrm{S}_{1 \mathrm{j}}+\mathrm{b}_{11}\left(\mathrm{x}_{1 \mathrm{ijk} k \mathrm{~m}}-\overline{\mathrm{x}}_{1}\right)+\mathrm{b}_{12}\left(\mathrm{x}_{\mathrm{ijk} k \mathrm{~m}}-\overline{\mathrm{x}}_{1}\right)^{2}+\mathrm{b}_{13}\left(\mathrm{z}_{\mathrm{ijk} k \mathrm{~m}}-\overline{\mathrm{z}}_{1}\right)+
\end{aligned}
$$

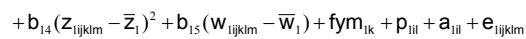

$$
\begin{aligned}
& y_{t i j k m}=B_{t i}+S_{t j}+b_{t 1}\left(x_{t j i k l m}-\bar{x}_{t}\right)+b_{t 3}\left(z_{i j k l m}-\bar{z}_{t}\right)+b_{t 4}\left(z_{i j k l m}-\bar{z}_{t}\right)^{2}+ \\
& +b_{t 5}\left(w_{t i j k m}-\bar{w}_{t}\right)+f y m_{t k}+p_{t i l}+a_{t i l}+e_{t i j k m}
\end{aligned}
$$

Matrix notation of the multiple trait model can be written as shown in Equation 3:

$$
\mathbf{y}=\mathbf{X} \boldsymbol{\beta}+\mathbf{Z}_{\mathrm{f}} \mathbf{f}+\mathbf{Z}_{\mathrm{a}} \mathbf{a}+\mathbf{Z}_{\mathrm{p}} \mathbf{p}+\mathbf{e}
$$

where $\mathbf{y}$ was a vector of observations on DMY, FC 
and PC. Matrix $\mathbf{X}$ was an incidence matrix and $\boldsymbol{\beta}$ a vector of unknown parameters for fixed effects. Vectors of unknown parameters were $\mathbf{f}$ for flock-test-month effect, $\mathbf{p}$ for permanent environment effect over lactation, and a for additive genetic effect. Corresponding incidence matrices were assigned as $\mathbf{Z}_{\mathrm{f}} \mathbf{Z}_{\mathrm{p},}$ and $\mathbf{Z}_{\mathrm{a}}$. Vector $\mathbf{e}$ was a vector of residuals.

Expected value of observations (Equation 4) was equal to $\mathbf{X} \boldsymbol{\beta}$, while expected values for all random effects were equal to zero.

$$
E\left[\begin{array}{c}
\mathbf{y} \\
\mathbf{f} \\
\mathbf{a} \\
\mathbf{p} \\
\mathbf{e}
\end{array}\right]=\left[\begin{array}{c}
\mathbf{X} \boldsymbol{\beta} \\
\mathbf{0} \\
\mathbf{0} \\
\mathbf{0} \\
\mathbf{0}
\end{array}\right]
$$

Variance components for individual random effects of flock-test-month (F), permanent environment over lactations $(\mathbf{P})$, additive genetic effect $(\mathbf{G})$, and residual (R) composed phenotypic variance (Equation 5). The structure of individual covariance matrices is presented in equation 6. Matrices $\mathbf{I}_{\mathrm{f}} \mathbf{I}_{\mathrm{p}}$, and $\mathbf{I}_{\mathrm{e}}$ are the identity matrices for the effects of flock-test-month, permanent environment over lactations, and residual. The order of the identity matrices is equal to number of levels for each random variable. Effects and levels for all random effects and residual were assumed to be uncorrelated, except for the additive genetic effect, where the relationship among levels is described by relationship matrix $\mathbf{A}$. The measurements are correlated within each level for individual random effect, what is shown with variances and covariances in matrices $\mathbf{F}_{0}$ for flock test month effect, $\mathbf{G}_{0}$ for additive genetic effect, $\mathbf{P}_{0}$ for permanent environment effect over lactations, and $\mathbf{R}_{0}$ for residual. Symbol $\Sigma^{\oplus}$ presents a direct sum. Due to animals with some missing records along lactation trajectory, the matrix of residual is a direct sum of matrices $\mathbf{R}_{0 \mathrm{k}}$. Residuals were assumed to be independent and normally distributed.

$\mathbf{V}=\operatorname{var}(\mathbf{y})=\mathbf{Z}_{\mathrm{f}} \mathbf{F Z}_{\mathrm{f}}{ }^{\prime} \mathbf{Z}_{\mathrm{a}} \mathbf{G Z}_{\mathrm{a}}{ }^{\prime}+\mathbf{Z}_{\mathrm{p}} \mathbf{P} \mathbf{Z}_{\mathrm{p}}{ }^{\prime}+\mathbf{R}$

$\operatorname{var}\left[\begin{array}{l}\mathbf{f} \\ \mathbf{a} \\ \mathbf{p} \\ \mathbf{e}\end{array}\right]=\left[\begin{array}{cccc}\mathbf{F} & \mathbf{0} & \mathbf{0} & \mathbf{0} \\ \mathbf{0} & \mathbf{G} & \mathbf{0} & \mathbf{0} \\ \mathbf{0} & \mathbf{0} & \mathbf{P} & \mathbf{0} \\ \mathbf{0} & \mathbf{0} & \mathbf{0} & \mathbf{R}\end{array}\right]=\left[\begin{array}{cccc}\mathbf{I}_{\mathrm{f}} \otimes \mathbf{F}_{0} & \mathbf{0} & \mathbf{0} & \mathbf{0} \\ \mathbf{0} & \mathbf{A} \otimes \mathbf{G}_{0} & \mathbf{0} & \mathbf{0} \\ \mathbf{0} & \mathbf{0} & \mathbf{I}_{\mathrm{p}} \otimes \mathbf{P}_{0} & \mathbf{0} \\ \mathbf{0} & \mathbf{0} & \mathbf{0} & \Sigma^{\oplus} \mathbf{R}_{0 \mathrm{k}}\end{array}\right]$

Basic statistical analysis was performed using GLM (General Linear Model) procedure by statistical package SAS (SAS, 2001). (Co)variance components for test-day records were estimated by restricted maximum likelihood (REML) from programme package VCE 5 (Variance Covariance Estimation; Kovač et al., 2002) by test interval method. Several runs of VCE 5 from different starting values were performed to ensure that the global maximum of the objective function was achieved.

\section{RESULTS AND DISCUSSION}

\subsection{PHENOTYPIC VARIANCE}

The phenotypic variance for DMY, FC, and PC was composed from (co)variance components for individual random effects of flock-test-month, permanent environment over lactations, additive genetic effect, and residual. Phenotypic variance for DMY (Table 3) was decreasing during the lactation, which is expected, since only the best animals and/or animals from the best flocks had observations at the end of lactation. For FC, the phenotypic variance is firstly decreasing after lambing toward the middle of lactation, and then it is increasing to the end of lactation. This variance is increasing along the lactation period in PC. Treating the flock-test-month effect as random caused the enlargement of the phenotypic variance for the observed milk traits. The effect is usually found in the fixed part of the model (Wilmink, 1987, Meyer et al., 1989). As seen from the literature, most authors treated only the additive genetic effect in the random part of the model in dairy cattle (Danell, 1982, Wilmink, 1987, Meyer et al., 1989) as well as in dairy sheep (Baro et al., 1994, Serrano et al., 2001, Volanis et al., 2002). Some of them (Swalve, 1995, Kominakis et al., 2001, Ilatsia et al., 2006, Tonhati et al., 2008) included the permanent environment effect over lactations in the random part as we did. Besides additive genetic effect, Andonov et al. (1998) took into account flock-test-month effect in the random part of the model for (co)variance estimation in Slovenian dairy goats. Due to different models mentioned in the literature, direct comparison of the results from this study is therefore difficult.

\subsection{VARIANCE RATIOS}

The heritability for DMY (Table 3) increased from the first $(0.15)$ to the fifth month of lactation (0.23). It decreased thereafter (down to 0.10 ). The largest amount of measurements was collected in the middle of lactation, thus the estimates at this period are more reliable compared to the estimates from early and late lactation. In the last months, only the best animals/flocks were still milked, which would reduce genetic variability. Baro et al. (1994) included only the additive genetic effect in the random part of the model for Churra sheep and divided lactation into three intervals (months). They obtained slightly higher heritabilities for DMY $(0.24,0.25$, and 0.16 ), while the trend was similar. The estimates in Boutsico sheep, where the lactation period was fragmented into eight months and random part of the model also contained permanent environment effect (Kominakis et 
Table 3: Variance ratios for random effects and phenotypic variance for milk traits during lactation Preglednica 3: Deleži variance za naključne vplive in fenotipska varianca za lastnosti mlečnosti med laktacijo

\begin{tabular}{|c|c|c|c|c|c|c|}
\hline Milk trait & $\begin{array}{l}\text { Month of } \\
\text { lactation }\end{array}$ & $\begin{array}{l}\text { Phenotypic } \\
\text { variance }\end{array}$ & Heritability & $\begin{array}{l}\text { Flock test } \\
\text { month }\end{array}$ & $\begin{array}{l}\text { Permanent environ- } \\
\text { ment of the animal }\end{array}$ & Residual \\
\hline \multirow[t]{8}{*}{ DMY } & 1 & 487345 & 0.15 & 0.24 & 0.12 & 0.49 \\
\hline & 2 & 303113 & 0.18 & 0.18 & 0.14 & 0.50 \\
\hline & 3 & 210369 & 0.22 & 0.21 & 0.13 & 0.44 \\
\hline & 4 & 128514 & 0.21 & 0.19 & 0.15 & 0.45 \\
\hline & 5 & 84761 & 0.23 & 0.20 & 0.12 & 0.45 \\
\hline & 6 & 68583 & 0.21 & 0.26 & 0.10 & 0.42 \\
\hline & 7 & 62565 & 0.14 & 0.36 & 0.09 & 0.41 \\
\hline & 8 & 63062 & 0.10 & 0.41 & 0.11 & 0.38 \\
\hline \multirow[t]{8}{*}{$\mathrm{FC}$} & 1 & 1.716 & 0.10 & 0.32 & 0.11 & 0.48 \\
\hline & 2 & 1.079 & 0.09 & 0.35 & 0.07 & 0.48 \\
\hline & 3 & 0.940 & 0.15 & 0.26 & 0.08 & 0.51 \\
\hline & 4 & 1.142 & 0.17 & 0.32 & 0.05 & 0.46 \\
\hline & 5 & 1.539 & 0.16 & 0.38 & 0.08 & 0.38 \\
\hline & 6 & 1.957 & 0.14 & 0.36 & 0.08 & 0.42 \\
\hline & 7 & 2.208 & 0.16 & 0.40 & 0.06 & 0.39 \\
\hline & 8 & 2.571 & 0.18 & 0.45 & 0.02 & 0.35 \\
\hline \multirow[t]{8}{*}{ PC } & 1 & 0.204 & 0.19 & 0.29 & 0.06 & 0.47 \\
\hline & 2 & 0.215 & 0.25 & 0.28 & 0.07 & 0.40 \\
\hline & 3 & 0.235 & 0.28 & 0.24 & 0.09 & 0.39 \\
\hline & 4 & 0.361 & 0.26 & 0.30 & 0.06 & 0.38 \\
\hline & 5 & 0.661 & 0.20 & 0.40 & 0.07 & 0.34 \\
\hline & 6 & 0.910 & 0.26 & 0.33 & 0.03 & 0.38 \\
\hline & 7 & 1.055 & 0.28 & 0.28 & 0.03 & 0.41 \\
\hline & 8 & 1.210 & 0.22 & 0.44 & 0.02 & 0.32 \\
\hline
\end{tabular}

al., 2001), ranged between 0.15 in the eighth month and 0.24 in the fifth month of lactation. Mid-lactation yields were also more heritable than those at the beginning and at the end of lactation. Higher estimates for DMY compared to our results were found by Serrano et al. (2001) in Latxa (0.20 to 0.33$)$ and Manchega sheep (0.17 to 0.26$)$ who divided lactation period into four months. Especially high heritabilities ( 0.41 to 0.47 ) were reported by Volanis et al. (2002) in Sfakia breed. A similar trend of heritability estimates for DMY compared to our results was reported by Andonov et al. (1998) in Slovenian dairy goats. The heritability increased from 0.18 in the third to 0.20 in the fifth month, and then declined down to 0.16 in the eighth month of lactation. The trend of heritability estimates for DMY in our research was also in accordance with dairy cows (Danell, 1982, Wilmink, 1987, Meyer et al., 1989, Pander et al., 1992, Swalve, 1995) and dairy buffalo (Tonhati et al., 2008), where estimates in the middle of lactation were higher than in early or late lactation. Relatively constant heritability estimates for DMY $(0.25$ to 0.30 ) during lactation were reported for dairy cows by Ilatsia et al. (2006). Our heritability estimates for DMY are mostly lower in comparison to the literature, but there are differences in the models, differences in the (co) variance structure, and also lack of pedigree data could be the reason for the obtained results. Actually, the pedigree is a source of information that enables the division of permanent environment and additive genetic effect.

Flock-test-month effect explains a relatively large amount of the phenotypic variance. This effect presents different technologies of sheep breeding and feeding manners among flocks including temporary events within flock on test-day or some days before, what is expressed in variance ratio for the effect. Flock-test-month effect presented about $20 \%$ of phenotypic variance in DMY from the beginning to the middle of lactation. The 
percentage rapidly increased toward the end of lactation up to $41 \%$. Andonov et al. (1998) reported about the oscillation of the variance for flock-test-month effect across lactation in Slovenian goats. The percentage amounted from $29 \%$ in the forth month to $36 \%$ in the seventh month of lactation.

Variance ratio for DMY explained by the permanent environment effect over lactations ranged between 0.09 in the seventh month and 0.15 in the forth month of lactation. The ratio slightly increased from the beginning to the middle of lactation and reduced thereafter. This effect relates to the rearing conditions of the ewe from its birth to the first parturition, affecting milk traits in all lactations. Results indicate that preparation of the ewes for reproductive life is more important in milk yield than in its components. In Boutsico sheep Kominakis et al. (2001) explained higher ratio for this effect, except in the first and in the third month of lactation. The ratio was between 0.08 in the early lactation and 0.42 in the eighth month. Tonhati et al. (2008) obtained smaller oscillation in the permanent environment variance ratio for DMY in dairy buffalos, which were between 0.10 and 0.20 across lactation.

Residual presented the largest (co)variance component among all components observed. In the first two months of lactation, it was around 50\%. It declined toward the end of lactation and was less than $40 \%$ in the last month. In study by Andonov et al. (1998) in Slovenian goats, the ratio for residual firstly decreased from 0.52 in the third month to 0.46 in the fifth month, and then it increased to 0.54 in the sixth month of lactation. The ratio then decreased again toward the last month of lactation to 0.52 . The ratio for residual was especially high in Boutsico sheep (Kominakis et al., 2001), which ranged from 0.62 in the forth month to 0.81 in the eighth month of lactation. It oscillated along lactation period. High values ( 0.50 to 0.75$)$ were obtained also in dairy buffalo by Tonhati et al. (2008), where the ratio firstly reduced from the first to the third month of lactation and it arised thereafter. Neither Kominakis et al. (2001) nor Tonhati et al. (2008) did include flock-test-month effect in the random part of the model, which could reduce the unexplained ratio of variance in the observed milk traits.

The heritability estimates for FC slightly increased from early toward the late lactation (Table 3). The lowest heritability for FC was found in the first two months (around 0.10). It increased almost two times to the last month (up to 0.18). Much higher heritability estimates for FC were shown by Volanis et al. (2002) in Sfakia sheep breed, which were in the range from 0.32 in the first to 0.52 in the forth month of lactation. Our estimates were lower compared to the estimates in Slovenian dairy goats by Andonov et al. (1998), where the heritability in- creased from the third (0.16) to the fifth month (0.29) of lactation, and it reduced thereafter. Danell (1982), Wilmink (1987), Meyer et al. (1989), Pander et al. (1992), and Swalve (1995) obtained the highest heritabilities for FC in dairy cows in the middle of lactation and the lowest at the beginning and at the end of lactation. The estimates from our study were lower than those in dairy cows.

Relatively a high variance ratio for FC was explained by the flock-test-month effect. Except the lowest variance ratio in third month of lactation (0.26), the estimates for this effect increased during lactation (to 0.45). The estimates were higher in comparison to the estimates by Andonov et al. (1998) found in Slovenian dairy goats, where the ratio for flock-test-month effect varied from 0.13 to 0.27 . Due to treating the effect as fixed, no other results were found in the literature.

The variance ratio for FC explained by the permanent environment effect over lactations diminished from the beginning (0.11) toward the end of lactation (0.02). The unexplained variance ratio in FC oscillated according to the month of lactation. Nevertheless, it decreased from the first to the last month of lactation ( 0.47 to 0.32$)$.

In PC, the heritability estimates accounted from 0.19 in the first to 0.28 in the third and in the seventh month of lactation (Table 3 ). The estimates oscillated during lactation. The estimates for PC were in accordance with those in Manchega sheep breed reported by Serrano et al. (2001), only that their heritability estimates arised in the early lactation and they declined after that. Much higher heritability estimates for PC were shown by Volanis et al. (2002) in Sfakia sheep breed, which were 0.44 in the first and 0.55 in the forth month of lactation. Furthermore, Meyer et al. (1989) obtained higher heritabilities for PC in dairy cows with the highest value in the middle of lactation (0.49) and lower (0.23) at the beginning and at the end of lactation. On the other hand Danell (1982) obtained a slightly lower heritability for PC in dairy cows, while the estimates by Wilmink (1987) in first lactation cows were lower at the beginning and at the end of lactation compared to our study, but slightly higher in the middle of lactation. Pander et al. (1993) estimated genetic (co)variances in dairy cows, but only for every second test day. However, the heritability estimates for PC were the highest in mid lactation and they were much higher in comparison to our results.

Variance ratio for the flock test month effect oscillated and ranged between 0.24 in the third to 0.44 in the last month of lactation (Table 3). Permanent environment effect over lactations explained much lower variance ratio in PC (0.02 to 0.09$)$. The percentage firstly increased from lambing to the third month of lactation, and then it decreased. Variance ratio in PC for residual 
was high (0.47), especially in the early lactation. The ratio decreased to 0.32 at the end of lactation.

\subsection{CORRELATIONS}

Additive genetic correlations for DMY between adjacent months of lactation (Table 4$)$ were high $(0.95$ to 0.98). The correlations decreased as the interval between months of lactation increased. The lowest additive genetic correlation for DMY (0.37) was estimated between the first and the last month of lactation. The structure of additive genetic correlations shows that DMY in the different stages of lactation is genetically not the same trait, since the correlations between distant months of lactation are lower than one. Results were in accordance with additive genetic correlations in Latxa and Manchega breeds, where Serrano et al. (2001) estimated the highest additive genetic correlations between adjacent months of lactation (0.87 to 0.97) and lower between distant months (0.46). Volanis et al. (2002) also published high additive genetic correlations for DMY between adjacent months (0.78 to 0.96$)$ in Sfakia sheep, which reduced with increasing time interval among test-days $(0.71$ between the first and the forth). The additive genetic correlation between the first and the second month of lactation in Boutsico breed was 0.99 (Kominakis et al., 2002). With increasing time interval among test-days, the correlations slightly decreased, thus the lowest additive genetic correlation was estimated to 0.45 , and was higher for 0.08 from ours. High additive genetic correlations for DMY between adjacent months of lactation were found also by Danell (1982) and Meyer et al. (1989) in dairy cows. The correlations decreased (to 0.22 ) when the interval between months of lactation increased. In the study of Pander et al. (1993), where estimates for every second test-day were reported, genetic correlations between distant months of lactation were still relatively high (up to 0.70 ). The additive genetic correlations for DMY between adjacent test-days estimated in the study of Ilatsia et al. (2006) in dairy cows were much lower (to 0.50 ) in comparison to our results. The correlations did not decrease with the increasing time interval among test-day records.

Additive genetic correlations for FC and PC followed similar pattern compared to DMY (Table 4). For FC, the correlations between adjacent months of lactation ranged between 0.82 and 0.98 . The correlations declined with the extending interval between test-days (to 0.49). They slightly increased between the months from early and late lactation (to 0.58 ), what could be the result of very few ewes from the best flocks with observations at the end of lactation. Between adjacent months of lactation the additive genetic correlations for PC were
Table 4: Additive genetic correlations for milk traits during lactation

Preglednica 4: Aditivne genetske korelacije za lastnosti mlečnosti med laktacijo

\begin{tabular}{|c|c|c|c|c|c|c|c|c|}
\hline $\begin{array}{l}\text { Milk } \\
\text { trait }\end{array}$ & $\begin{array}{l}\text { Month of } \\
\text { lactation }\end{array}$ & 2 & 3 & 4 & 5 & 6 & 7 & 8 \\
\hline \multirow[t]{7}{*}{ DMY } & 1 & 0.97 & 0.86 & 0.76 & 0.65 & 0.61 & 0.46 & 0.37 \\
\hline & 2 & & 0.95 & 0.89 & 0.81 & 0.76 & 0.62 & 0.56 \\
\hline & 3 & & & 0.98 & 0.94 & 0.90 & 0.81 & 0.78 \\
\hline & 4 & & & & 0.99 & 0.95 & 0.87 & 0.86 \\
\hline & 5 & & & & & 0.98 & 0.92 & 0.92 \\
\hline & 6 & & & & & & 0.97 & 0.95 \\
\hline & 7 & & & & & & & 0.98 \\
\hline \multirow[t]{7}{*}{$\mathrm{FC}$} & 1 & 0.95 & 0.71 & 0.63 & 0.54 & 0.49 & 0.59 & 0.58 \\
\hline & 2 & & 0.82 & 0.70 & 0.57 & 0.48 & 0.56 & 0.64 \\
\hline & 3 & & & 0.95 & 0.87 & 0.77 & 0.64 & 0.81 \\
\hline & 4 & & & & 0.94 & 0.87 & 0.75 & 0.86 \\
\hline & 5 & & & & & 0.98 & 0.83 & 0.90 \\
\hline & 6 & & & & & & 0.87 & 0.90 \\
\hline & 7 & & & & & & & 0.95 \\
\hline \multirow[t]{7}{*}{ PC } & 1 & 0.90 & 0.78 & 0.58 & 0.43 & 0.25 & 0.18 & 0.09 \\
\hline & 2 & & 0.96 & 0.81 & 0.66 & 0.49 & 0.41 & 0.35 \\
\hline & 3 & & & 0.94 & 0.81 & 0.64 & 0.55 & 0.55 \\
\hline & 4 & & & & 0.94 & 0.79 & 0.64 & 0.71 \\
\hline & 5 & & & & & 0.95 & 0.80 & 0.85 \\
\hline & 6 & & & & & & 0.91 & 0.90 \\
\hline & 7 & & & & & & & 0.96 \\
\hline
\end{tabular}

all above 0.90 . The correlations for PC rapidly decreased with rising distance between test-days, down to 0.09 between the first and the last month of lactation. The correlations for FC in Sfakia sheep breed, obtained by Volanis et al. (2002), were mainly higher compared to our study, while some of them were similar to our estimates. They estimated the lowest additive genetic correlation between the first and the fourth month 0.79 for FC and 0.85 for PC), and the highest between the first and the second month of lactation (0.99). In dairy cows, the additive genetic correlations for FC between adjacent months (Danell, 1982) were similar to ours, but they were slightly lower for PC (0.71 to 0.86). Pander et al. (1993) also estimated high additive genetic correlations between adjacent months of lactation in bimonthly test-day analysis. All the additive genetic correlations in the cited studies diminished with the increasing interval between testdays. A larger range (0.61 to 0.99 ) of additive genetic correlations for PC between adjacent months was published by Serrano et al. (2001) in Manchega sheep breed for 
four months of lactation. The correlations decreased up to 0.50 with the rising distance between test-days.

\section{CONCLUSIONS}

Milk traits in three Slovenian dairy sheep breeds were studied by the test-interval method. Heritability estimates for DMY were the highest in the middle of lactation, and lower at early and late lactation. For FC, the estimates increased from the beginning to the end of lactation, while heritability in PC increased after lambing, and then oscillated toward the end of lactation. Heritability estimates for DMY, FC, and PC were lower in comparison to the literature. Differences in estimates appeared mainly due to fitting flock-test-month effect as random and due to inclusion the permanent environment effect over lactations into the model. Additive genetic correlations between adjacent months of lactation were high, close to one, in all three milk traits. They decreased when the interval between months of lactation increased. The structure of additive genetic correlations showed that the observed milk traits in different stages of lactation genetically are not the same traits, since the correlations between distant months of lactation were lower than one. A further research is required to study the use of random regression models in genetic evaluation, which allow the estimation of the lactation curve within animal.

\section{ACKNOWLEDGEMENT}

The authors gratefully acknowledge Špela Malovrh, Ph.D. and Gregor Gorjanc, Ph.D. for their technical and professional assistant.

\section{REFERENCES}

Ali T. E., Schaeffer, L. R. 1987. Accounting for covariances among test day milk yields in dairy cows. Canadian Journal of Animal Science, 67: 637-644

Andonov S. 1994. Estimation of genetic parameters for milk production in dairy goats using the first records of lactation. Master of Science Thesis, Univ. of Ljubljana, Biotechnical Fac., Zootechnical Dep., Domžale: 68 p.

Andonov S., Kovač M., Kompan D., Dzabirski V. 1998. Estimation of covariance components for test day production in dairy goat. In: Proceedings of the 6th world congress on genetics applied to livestock production, Vol. 24, Armidale, Australia, 11-16 Jan. 1998, University of New England, Armidale. $145-148$

Baro J. A., Carriedo J. A., San Primitivo F. 1994. Genetic parameters for milk yield and somatic cell counts at several lactation stages in milking ewes. In: Proceedings of the $5^{\text {th }}$ world congress on genetics applied to livestock production, Vol. 18, Guelph, Canada, 7-12 Aug. 1994, Canada: 115-118 Brežnik S. 1999. Ocenjevanje parametrov disperzije za lastnosti mlečnosti pri ovcah (Estimation of dispersion parameters of sheep milk traits). Master of Science Thesis, Univ. of Ljubljana, Biotechnical Fac., Zootechnical Dep., Domžale, $73 \mathrm{p}$.

Danell B. 1982. Studies on lactation yield and individual testday yields of Swedish dairy cows. II. Estimates of genetic and phenotypic parameters. Acta Agriculturae Scandinavica A, 32: 83-92

El-Saied U. M., Carriedo J. A., Baro J. A., De La Fuente L. F., San Primitivo F. 1998a. Genetic and environmental estimations for test-day and standardized milk yield of dairy sheep. Small Ruminant Research, 27: 209-215

El-Saied U. M., Carriedo J. A., Baro J. A., de la Fuente L. F., San Primitivo F. 1998b. Genetic correlations and heritabilities for milk yield and lactation length of dairy sheep. Small Ruminant Research, 27: 217-221

Everett R. W., Carter H.W. 1968. Accuracy of test interval method of calculating Dairy herd improvement association records. Journal of Dairy Science, 51, 12: 1936-1941

ICAR 2009. International agreement of recording practices. USA, Niagara Falls, 475 pp. http://www.icar.org/Documents/Rules\%20and\%20regulations/Guidelines/Guidelines 2009.pdf (7. oct. 2010)

Ilatsia E. D., Muasya T. K., Muhuyi W. B., Kahi A. K. 2006. Use of test day milk yield records for genetic evaluation in Sahiwal cattle. In: Proceedings of the $8^{\text {th }}$ world congress on genetics applied to livestock production, Belo Horizonte, Brasil, 13-18 Aug. 2006, Brasil: 1-61

Kominakis A., Volanis M., Rogdakis E. 2001. Genetic modelling of test day records in dairy sheep using orthogonal Legendre polynomials. Small Ruminant Research, 39: 209-217

Komprej A., Gorjanc G., Kompan D., Kovač. M. 2009. Covariance components by repeatability model in Slovenian dairy sheep using test-day records. Czech Journal of Animal Science, 54, 9: 426-434

Kovač M., Groeneveld E., Garcia-Cortes L.A. 2002. VCE 5, a package for the estimation of dispersion parameters. In: Proceedings of the $7^{\text {th }}$ world congress on genetics applied to livestock production, Vol. 33, Montpellier, France, 19-23 Avg. 2002, INRA, Castanet-Tolosan, France: 741-742

Meyer K., Graser H.U., Hammond K., 1989. Estimates of genetic parameters for first lactation test day production of Australian black and white cows. Livestock Production Science, 21: 177-199

Oravcova M., Groeneveld E., Kovač M., Peškovičova D., Margetin M. 2005: Estimation of genetic and environmental parameters of milk production traits in Slovak purebred sheep using test-day model. Small Ruminant Research, 56: 113-120

Pander B.L., Hill W.G., Thompson R. 1992. The effect of increasing interval between recordings on genetic parameters for test day yields of British Holstein-Friesian heifers. Animal Production, 56: 159-164

Pander B.L., Thompson R., Hill W.G. 1993. Genetic parameters for test day records of British Holstein-Friesian heifers. Animal Production, 55: 11-21 
Portolano B., Montalbano L., Militi W. 2001. Genetic and environmental sources of variation for milk yield traits in Barbaresca siciliana breed. Small Ruminant Research, 41: 195-202

Ptak E., Schaeffer L.R. 1993. Use of test day yields for genetic evaluation of dairy sires and cows. Livestock Production Science, 34: 23-34

Sargent F.D., Lytton V.H., Wall O.G. 1968. Test interval method of calculating Dairy herd improvement association records. Journal of Dairy Science, 51, 1: 170-179

SAS Institute Inc. 2001. The SAS System for Windows, Release 8.02. Cary, NC, USA

Schaeffer L.R., Jamrozik J. 1996. Multiple-trait prediction of lactation yields in dairy cows. Journal of Dairy Science, 79: 2044-2055

Schaeffer L.R., 1998. Random regression models. PhD Course, Wageningen, 13-17 July 1998, Wageningen, Wageningen institute of animal sciences: $147 \mathrm{p}$.

Serrano M., Ugarte E., Jurado J.J., Perez-Guzman M.D., Legara A. 2001. Test day models and genetic parameters in Latxa and Manchega dairy ewes. Livestock Production Science, 67: $253-264$
Swalve, H.H. 1995. The effect of test day models on the estimation of genetic parameters and breeding values for dairy yield traits. Journal of Dairy Science, 78: 929-938

Swalve, H.H. 2000. Theoretical basis and computational methods for different test-day genetic evaluation methods. Journal of Dairy Science, 83, 5: 1115-1124

Tonhati H., Cerón-Muňoz M. F., de Oliviera J. A., El Faro L. 2008. Test-day milk yield as a selection criterion for dairy buffaloes (Bubalus bubalis Artiodactyla, Bovidae). Genetics and Molecular Biology, 31, 3: 674-679

Vargas B., Perez E., Van Arendonk J.A.M. 1998. Analysis of test day yield data of Costa Rican dairy cattle. Journal of Dairy Science, 81: 255-263

Volanis M., Kominakis A., Rogdakis E. 2002. Genetic analysis od udder score and milk traits in test day records of Sfakia dairy ewes. Archiv für Tierzucht, 45, 1: 69-77

Wilmink J.B.M. 1987. Efficiency of selection for different cumulative milk, fat and protein yields in first lactation. Livestock Production Science, 17: 211-224 